Educational Research for Social Change (ERSC)

Volume 8 No. 1, April 2019

pp. 41-53

ersc.nmmu.ac.za

ISSN: 2221-4070

\title{
Using Photographs as Memory Prompt Objects: Influencing Pre- Service Language Teachers To Recognise Reading as a Driver of Social Change
}

\author{
Bridget Campbell \\ University of kwa-Zulu Natal \\ campbell@ukzn.ac.za \\ Bonakele Mhlongo \\ University of kwa-Zulu Natal \\ mhlongob2@ukzn.ac.za
}

\section{Abstract}

The power of literacy is such that it has the ability to drive social change. This narrative inquiry study, which is informed by sociocultural theory, was inspired by the 2016 Progress in International Reading Literacy Study report. The report, which indicated that $80 \%$ of South African Grade 4 children cannot read for meaning, encouraged two teacher educators to investigate our literacy journeys. We selected objects that represent our literate life histories and wrote about our individual visual representations before discussing our objects. The objects selected were photographs of a father and his daughter and of a pile of books. Through our objects, this article identifies what shaped our reading proficiencies, and explores ways in which we can influence pre-service language teachers to recognise reading as a driver of social change. Our interactions with our chosen objects brought us to the realisation that, in spite of our multifarious backgrounds, our common literacy experiences enabled us to become proficient readers through which we gained access to higher education and academic success.

Keywords: photograph, reading, early literacy experiences, academic success, social change

\section{Copyright: (c) 2019 Bridget Campbell and Bonakele Mhlongo}

This is an open access article distributed under the terms of the Creative Commons Attribution NonCommercial License, which permits unrestricted non-commercial use, distribution, and reproduction in any medium, provided the original author and source are credited.

Please reference as: Campbell, B. \& Mhlongo, B. (2019). Using Photographs as Memory Prompt Objects: Influencing Pre-Service Language Teachers To Recognise Reading as a Driver of Social Change. Educational Research for Social Change, 8(1), 41-53.

http://dx.doi.org/10.17159/2221-4070/2018/v8i1a3 


\section{Background}

The Progress in Reading International Literacy Study (PIRLS) assesses comprehension prowess of Grade 4 learners at 5-year intervals. In the 2016 PIRLS report, South Africa scored last out of 50 participating countries. Spaull (2017) summarised the main findings of the report, and findings pertinent to this study are that $78 \%$ of South African Grade 4 learners are not able to read for meaning, which is far below the global average with America's percentage standing at 4\%, England's at 5\%, Chile's 13\%, and Iran's at $35 \%$.

These results are fundamentally the same as those yielded by the 2006 PIRLS assessments - the year when South Africa first participated in PIRLS. Howie (2010) reported that the South African Grade 5 learners' results were the lowest in the study despite the fact that they were being compared with the Grade 4 learners internationally. The most disturbing aspect of the 2016 PIRLS report, though, is that the South African scores indicate that South Africa might be six years behind the top performing countries.

This article emanated from the discussions of two colleagues about the abysmal 2016 PIRLS results. We are pre-service teacher educators and colleagues in a school of education in KwaZulu-Natal. Bridget is situated in the English discipline and Bona in the isiZulu discipline. Bridget is one of three sisters, and was born in South Africa in the 1960s to a white, middle-class Christian couple. Her mother was a teacher and her father, a mine surveyor. Bona was born in the late 1950 s to a black middle-class South African family. She is the youngest in the family and has two brothers. Both her parents were teachers. The two of us spoke of our own literacy experiences, in which the common feature is that we were exposed to books and other print materials at school and home, and we were encouraged to visit libraries on a weekly basis. We are both avid readers and have noted that many of our students do not read the books prescribed in the curriculum. What we find worrying is that in conversations about the importance of reading, many of the pre-service teachers in our classes state that they do not read for recreation, and that they often rely on online notes and films for their university literature studies, rather than reading the novels.

\section{Theoretical Stance}

The study is underpinned by sociocultural theory wherein Vygotsky (1978) proposed that social interaction begins in the home, and plays a vital role in the development of children. Learning occurs through participation in settings such as family life, peer group interaction, in schools, and in the workplace (Lantolf \& Thorne, 2007).

According to van Boxtel (2000), sociocultural theory is based on the idea that language and culture intercede during the process of knowledge construction. In negotiating their way around the activities and demands of their environment, children are initially dependent on others who initiate them into the ways of doing and being and, as they become more knowledgeable and confident, they become self-sufficient. This process is referred to as scaffolding, which is a teaching strategy emanating from Vygotsky's (1978) sociocultural theory. A child who is exposed to print materials and read to from an early age is interacting with the reader and, whilst being exposed to a world outside the immediate surroundings, knowledge construction is taking place. This will be an advantage when the child is confronted with learning to read at school and beyond when faced with the demands of reading for academic success in higher education. 


\section{Methodology}

The methodological approach adopted in this study was arts-based narrative inquiry; we employed techniques from both arts-based and narrative inquiry research methodologies. Connelly and Clandinin (1990) stated that narrative researchers gather stories about happenings in their lives and then write narratives about these encounters; the point of departure of this study was to tell our lived literacy experiences and to depict these through objects. Clandinin (2006) noted that, although narrative inquiry has a long history, both in and out of education, it has become popular in studies of educational experience and, in this study, we examine our literacy experiences through the telling of our personal stories. In the telling of our literacy stories, we were making meaning from experience (Kitchen, 2009) as we tried to identify how it came about that two South Africans from very diverse sociocultural backgrounds, and who grew up during the apartheid era, came to be colleagues teaching pre-service teachers in the disciplines of English and isiZulu. In sharing our literacy journeys, we used narrative as a way of making meaning of our lived literacy experiences (Pithouse, 2011).

As scholars from diverse backgrounds, we have, over the years of working together, discussed collaborating in our research and it was our concern about the PIRLS report that afforded us the opportunity to research together. Mitchell and Pithouse-Morgan (2014) devised a protocol for collective storytelling and memory work, and one of the points is that once a topic has been selected, the participants must then agree on how their life histories will feed into the topic; we followed this advice. Once we had agreed to select objects as our memory prompts, the starting point for our research was to ask ourselves: "Which things, and what do they mean?" (Mitchell, 2017, p. 26). We chose to select photographs as memory prompt objects for examining our literacy experiences because objects have personal, sociocultural, or historical significance (Prown, 1982) and visual elicitation involves using photographs, drawings, or diagrams as a stimulus (Prosser, 2011). In his work, Riggins (1994) highlighted the denotative (literal) meanings of things along with the connotative (social, emotional, cultural, associated) meanings, and it was in the connotative meanings that we found many of the answers to our question as to what shaped our literacy journeys. What was interesting is that, in writing about our pictures, we were giving attention to what could not be seen and what was not known (even to ourselves) until we started interrogating them. Clandinin and Connelly (2000) wrote of the relationship between living a life story, telling the story, and reliving that story. This is what we were doing too: we had lived our early literacy life stories through our conversations, and we then retold them through our images.

After selecting our images (the images cannot be included due to issues of copyright), we sat together and examined them and we each spoke about what they meant to us, and why we had made those selections. Bona had selected a photograph of her father and herself. The photo is of Bona standing next to her father who is seated in a chair. She is wearing her school uniform and is standing right next to her father and smiling shyly. Her father is formally dressed in a jacket and tie and looks relaxed with his open hands placed on his knees. Warner (2004) said of the photograph that it connects the moment when the subject was there, with the present moment. This is true of Bona's photograph because the image immediately conjured up memories of her father and his love affair with reading, and she understood from whence her love of reading had emanated. She feels overwhelmingly grateful to her father for the opportunities she has garnered as a result of her reading.

Bridget's image was a photograph she had recently taken of childhood books and long-playing records. The image included a book of Bible stories, The Voyages of Dr Doolittle (Lofting, 1967), The Tale of Peter Rabbit (Potter, 1940), a long-playing record of songs for children, and another long-playing record with a song about being cheerful and whistling while we work. Bridget described coming across a treasure trove of childhood favourites when clearing out her parents' garage as an emotional experience that sparked memories of singing along whilst listening to children's records, of being read 
to by her mother when tucked up in bed, and of the excitement of learning to read by herself. Like Bona, she feels grateful to her parents for instilling a love of reading in her.

In our discussions about the images, we agreed that we wanted to interrogate ways in which our chosen images spoke to us. We decided to work independently as we considered the denotative and connotative meanings of our photographs, and agreed to find ways in which to present the images to one another.

Bona chose to present her picture through five diary entries that she wrote retrospectively: two written at age 11 years, one at age 16, one at age 18, and the final entry written as reflections from her adult self in 2018. Bridget wrote a poem depicting her interpretation of her image in relation to her literacy journey. This exercise followed the advice of Mitchell and Pithouse-Morgan (2014) who recommended that participants write independently about their memories.

\section{Bona's interpretation of her photograph}

Bona's diary entries (below) highlight awareness that, as a child, she resented that she was forced to read. The later diary entries indicate that her adult self is appreciative of the opportunities that reading has afforded her. She now acknowledges that reading is a privilege that allowed her to achieve academically.

\section{Excerpts from my diary: Age, 11 years}

Sunday, April 27, 1969

Today is Sunday! I love Sundays because other than going to church, this is the day reserved for dessert! I wonder what mum has in store for us today! I sure hope it's much better than grandma's bread-and-butter pudding. But, then after lunch, Dad's reading sessions! Eish-today it will be longer than the usual 15 minutes because of the Sunday Tribune newspaper. It is too thick!!!

Monday, July 21, 1969

These holidays are not so great. Reading, reading, and more reading! I'm glad tomorrow we are going back to school. No more reading hours! But I must admit that yesterday's paper had many interesting news stories! People who went to visit the moon! I will look at the moon differently from now. It is kind-of another planet! Imagine that you need to carry your own oxygen! Anyway, I am still glad that it is back to school tomorrow with time to play and not being forced to read.

\section{Excerpts from my diary: Age, 16 years}

\section{Friday, November 1, 1974}

This year has flown! This is my last year in secondary school then I have two more years in high school and, hey, college! My reading sessions with Dad have finally paid off. I received the Best English Pupil in Standard 8 award. I did very well in both the vocabulary quiz and oral presentation. I knew the meaning of words such as "sextuplets" from reading the article on the Rosenkowitz babies born in Cape Town ... and my favourite new word, "coup d'état." I can vividly remember Dad explaining this word from an article in The Daily News. It was all about what had happened in Portugal. Dad is so proud of me and says that I received the award as a result of our reading sessions. I suppose that he is correct.

Dad is so thrilled that one of the reward tokens is a book by George Orwell entitled, Animal Farm. This might just ruin my summer holidays though... Dad will want me to read this book and finish it by the 
time schools reopen in next year. It's okay-maybe it's not a bad idea since our principal said the book is one of the set books I will read in high school.

\section{Excerpts from my diary: Age 18, years}

\section{Thursday, November 25, 1976}

This was the best day of my life! I wrote my last final exams in high school, and I'm expecting to pass and next year I'm off to college. My dad works on the South Coast now, and only comes home twice a month. I suppose that his promotion could be partly to do with the fact that he is a learned man and this must be as a result of his reading. Perhaps I should take reading more seriously. The fact that Dad is away has been a blessing in disguise as I had so much work to do the whole year and would not have had time for extra reading sessions. For the first time everything makes sense! Guess what-Animal Farm was one of the prescribed books for matric. Another reason to be grateful for my reading ability. My English teacher was surprised that I'd read the book and was quite familiar with terms such as allegory, satire, revolution. Thanks Dad! I really do owe this to you. I had even read some of my isizulu books and found them easy as two of the prescribed books I read years ago at home are in your exclusive collection.

\section{Reflections from an adult perspective}

Tuesday, 15 May, 2018

As I pondered on the article about the importance of literacy with my colleague, from the perspective of a language teacher, I had to reflect on my personal journey with regards to literacy. My reading experiences with my dad from the age of nine years until about 16 stand out. With hindsight, I know and appreciate the role played by my dad in shaping my academic journey during the era of racial discrimination in South Africa. My dad was a language teacher of both IsiZulu and English and, in his day, had had the privilege of being schooled at some of the best schools. The impact of the education he received was evident in the effort he put into getting us ahead in our schoolwork. There were just two children in the house: my older brother and myself. Our eldest sibling lived with my grandma, grandpa, and uncle who was my father's eldest brother. At home, we always received lots of attention and our school needs came first. This in itself was rare in many black families.

On reflection, my brothers and I achieved academically in different fields on matriculating. I am of the opinion that we coped with the demands of university because of our strong literacy backgrounds. When I think of our contemporaries from the apartheid era, there are many of my peers who either did not get into university, or dropped out before graduation. Many of my friends had absent fathers who were migrant labourers, or parents who did not have the luxury of giving their children attention because life was a battle. It is understandable that many of my friends did not achieve much after leaving school.

As a successful academic, I have become aware of the importance of early exposure to literacy. Several studies highlight the weak literacy levels of students in higher education institutions. For instance, McKenna's (2010) research stated that $56 \%$ of black students drop out of their studies because of being academically under prepared. Poor reading ability is cited as one of the most common characteristic among students with underdeveloped academic literacy skills. I did not have that problem thanks to my dad. Grabe (1991) observed that reading is at the core of all formal education. In the academic context, literacy involves navigating through extensive information sources, which requires an advanced reading ability. Students' inability to read also impacts on their ability to write, which further exacerbates their academic plight. I had little trouble writing, and attribute this to the fact that I am a fluent reader. Baruthram (2012) suggested that the reason for poor writing is that poor readers are 
unable to model their own writing on the linguistic and structural features of read texts. I am thus grateful to be an avid reader.

\section{Bridget's Interpretation of Her Photograph}

Bridget shares similar sentiments in her interpretation of her picture and her poem. She indicates that she is also grateful for her childhood reading experiences, as depicted in her poem below which highlights awareness that her white privilege allowed her to access to knowledge through reading. She acknowledges that she might not be in her current position as a pre-service teacher educator had the required tools to academic success been accessible to all South Africans.

\section{The Magical Library}

\section{Mbali gets us dressed}

With bows in my curly brown hair

We are off to a magical place with Mother-the library

Three excited sisters-skin so fair.

It's my favourite place to visit

Getting lost in Enid Blyton's, The Faraway Tree.

I asked Mbali to join in the fun but she says that she has work to do and will wait at home

Oh well-I think she can't read, so it does not matter that she won't come with me.

As we make our way along the pavement

We sing the alphabet song in excitement and chat to our mum,

Out the corner of my eye, I see a little brown boy playing in the dirt

And wonder out loud if perhaps he is Mbali's son.

When we walk through the giant library doors with the whites-only sign on it, I know exactly which shelf I am headed for

"B" for Blyton and the folk of the faraway tree,

Today I battle to get lost in the story as all I can think about is the brown boy I saw.

I wonder where the boy is from, does he go to school? Can he read?

I decide that I will ask Mother when she picks me up from the library-maybe she will know.

Mother has bought me a new book-such excitement! By the time we arrive home, I have forgotten about the boy with the brown face,

We have a treat, a bath and then supper ... my sisters and I decide to put on a show.

The next time we visit the library, there he is again

He looks skinny, dirty and sad. He is sniffing and really needs a tissue

I stop and stare and ask if I may say hello-I still have the urge to take him into the magical library

My mother refuses, and I shrug and really don't see the issue.

As summers roll into winters and winters into spring the library remains one of my favourite places to spend my time and I now walk there alone

Over the years the boy with the brown face, who is now a tall skinny man in threadbare clothes, and I have become silent friends

Every time I walk by, we wave and share a smile but never do we exchange a word I see him often as he now works in the garden of Mr and Mrs Barends.

The years roll by and my sister Megan has a boyfriend, and Susan has gone off to nurse 
Walking alone, I fight the urge to chat with the familiar brown face

I wonder as to his name, what his voice sounds like, did he go to school? Did he learn to read?

I never approach him because the last thing I need is the neighbours whispering, or my parents on my case.

I am married with three beautiful sons of my own

Sometimes I think about the friend I never met when I read the boys a bedtime book

In my heart, I know that the boy was never tucked up in a warm bed, and that he didn't ever hear the story of the faraway tree

I now wonder if he even noticed my magical library and longingly give it a second look.

I sit at my desk marking English papers

My students are from every South African race

Which of them have literate parents? Which of them went to the library as a child?

Did they have bedtime stories after brushing their teeth and washing their faces?

As I get older, I reflect on my life, question my white privilege and the opportunities I have had If knowledge is power then I surely I had a head start!

\section{Discussion}

We shared our interpretations of our pictures - the diary entries and the poem - and decided to work independently as we examined our own and then each other's writing. We agreed to identify the emerging themes in the diary entries and the poem. After examining both the diary entries and the poem Bona identified a number of common themes: reading from an early age, exposure and access to knowledge through reading, parental support, academic achievement, desire to instil the same in our own children and those in our care and discipline.

What Bridget did when looking at the diary entries and the poem was to follow the trajectories of both pieces, and she noted that both she and Bona were exposed to books and read to from a young age. They both read independently once they had learned to read. Bridget enjoyed both the reading sessions with her mother and reading on her own. Bona, on the other hand, did not enjoy her reading sessions and resented the fact that her father forced her to read. Another commonality that Bridget noted in her analysis of the two written pieces was that both she and Bona attribute their academic success to their reading prowess. On the realisation that, in the days of apartheid, being forced to read privileged her, Bona displays immense gratitude to her father. Like Bona, Bridget's reflections led her to thinking about apartheid in South Africa. She also sees her reading and academic success as a privilege. What differs from Bona's privilege is that Bridget acknowledges that her privilege was a result of being a white South African during apartheid. A final commonality noted by Bridget is that both she and Bona acknowledge the important role that reading has in all aspects of their lives.

Having identified the commonalities and differences discussed above, we worked together and exchanged our views about the commonalities as advised by Mitchell and Pithouse-Morgan (2014). We were moving back and forth from the particular to the general as we worked with our objects. In our discussions, we related the themes to literature about the importance of reading. This took us into the realm of the general. The analysis then moved back to the particular as we honed in on the 2016 PIRLS report and research on the importance of learning to read and reading to learn.

In this to-and-fro, we were working within the gaps between our personal stories, national global research on reading, and ways in which we can encourage our pre-service teachers to realise the 
importance of reading. Fine (1998) termed this process of analysing our stories as working the hyphens, which she described as initiating opportunities for discussions around what is and what is not happening in relation to the stories and their interpretations and whose story is being foregrounded.

In discussions about the connotative meanings of what emanated from our images, Bridget noted that she was astounded at what her poem revealed about her life as a young white girl growing up in apartheid South Africa during the 1960s and 1970s. A seemingly simple picture of her favourite books and records had elicited memories about her childhood. For example, she writes of Mbali-the helper who cleaned, cooked, and assisted with the children-dressing the three sisters in a manner that was obviously respectable for being seen in public. Only when the girls were ready, did Bridget's mother feature - and it is the mother who took them to the library, not Mbali. On analysis of the poem, Bridget made the observation that she had stated that the library had a whites-only sign outside, which explains why Mbali stayed at home. Mbali was excluded from the library because she was not white. The question as to whether or not Mbali was able to read did not enter the little girls' minds. The little girls were happy, and clean, and chatty and it is really as an aside that Bridget mentions that she noticed the brown boy playing in the dirt. He was not white and would not have access to the library and the knowledge therein. It is not surprising that when Bridget interrogated her picture, it made her think of the apartheid era and white privilege which is defined by McIntosh $(1988$, p. 1) as being "like an invisible weightless knapsack of special provisions, maps, passports, codebooks, visas, clothes, tools and blank cheques." Race is important to both authors' stories because they grew up during the apartheid era in South Africa, and Yancy and Davidson (2014, as quoted in Carr, 2016, p. 54) wrote that:

race matters because of the lived experiences and historical realities that have placed racial identity at the centre of how countries and people have been organised in relation to socially constructed hierarchies that have always placed the white race at the pinnacle.

Bridget's making mention of the little boy of a different race points to an underlying awareness of the social hierarchy determined by race. The magic of the library did not make Bridget forget about the boy - now out of sight-and she began to wonder about him and his access to reading and school. This points to awareness of the importance of books in the life of a child. The instant she arrived home and had a new book, which would empower her in her academic life, all thoughts of the brown boy disappeared. For a brief moment, she had been confronted with a child who did not have her privileges and she displayed concern until she was in the comfort of her home-and then she forgot all about him. At the end of the poem, Bridget acknowledges that her whiteness and her literacy journey have always been an advantage that she has taken for granted.

With Bona, the connotative meaning that could be extracted from her image could also be interpreted as privilege, considering the South African political and economic climate when she was growing up in the early 1970s and 1980s. Migrant labour laws deprived many black households of the luxury of an ever present father figure and even though her father moved away from home, he was still very much a presence in the life of Bona's family. To be encouraged to read was a privilege because exposure to reading material such as books and newspapers was a luxury, and for some members of society only. The fact that both Bona's parents were professionals gave her an edge over her peers at school, as reflected in her diary entries. Unlike Bridget, Bona did not have access to libraries at school or close to her home because they were not part of the infrastructure of African communities during apartheid. Poor schooling infrastructure has been identified as one of the hallmarks of the apartheid schooling system (Thobejane, 2013). Thobejane (2013) further noted that racially segregated schooling provided blacks with the minimum standard of education necessary for menial labour. 
Within the confines of the social, economic, and political exclusion that Bona's family faced during apartheid in South Africa, her father used reading as a tool to empower his children. Bona, like Mbali who worked for Bridget's family, would not have been allowed to go into the library with Bridget; and Bona's father compensated for this with reading activities in the home. The seemingly simple act of reading a newspaper, which became a family ritual, appeared to have had the desired educational impact given that Bona achieved academic success, which she partly attributes to her father. As a language teacher, Bona's father seems to have been acutely aware of the role of reading as an important tool for accessing knowledge. In revisiting her diary entries, Bona recalled that apart from reading, some of the other fun activities the family engaged in included playing word games, morabaraba (which is similar to chess), and solving riddles. All these activities, in her words, supported her development of writing and critical thinking skills. In our later discussions, she added that, as an educator, her father was very politically aware and realised that educational intervention needed to be initiated to bring about social change. Because of her father's interventions, Bona stated that she was acutely aware of the racial, economic, and social disparities in South African society.

It is interesting to note that even though Bona's dad eventually worked away from home, he controlled her reading habits from afar. She says that when he was promoted to a deputy principal position in a school it became difficult to commute daily. This happened when Bona was in her matric year, and beyond her early years of literacy development, so the foundation of her academic success had already been built. Yeo, Ong, \& Ng (2014) stated that the most effective predictor of children's burgeoning reading ability and interests is directly related to parents being actively involved, and we are of the opinion that this holds true in both our cases. The sociocultural environment in which we were raised, presented us with tasks and demands with which we had to engage as noted by Vygotsky. Vygotsky (1978) claimed that the child is completely dependent on other people, which was the case with us because we relied on our parents to read to us and to expose us to appropriate reading materials. Wertsch (1991) made the point that individual development has its origins in social and cultural sources and that, as interaction is taking place, knowledge is internalised to be available when needed.

Our discussions about the diary entries and the poem centred on the pivotal role that our parents and reading played from the onset of our literacy development. We are cognisant of the fact that as preservice teacher educators of isizulu and English we are well placed to encourage our teachers of the future to read and to undertake the responsibility of coaxing those entrusted into their care to become readers. The themes of reading from a young age with parental support, acknowledgement of the importance of reading, and the link between reading and academic success are what we agreed to focus on when deciding how to foster a culture of reading in our students. The theme of privilege was predominant in both stories, with the privilege of reading central to Bona's story and white privilege playing a part in Bridget's story. Many of our students will teach in schools that are underprivileged, and we resolved to make our students aware that they can contribute to positive social change in their communities by giving their learners the privilege that comes with reading with understanding in order to learn. We agreed that the correlation between reading and academic success is what needs to be at the forefront of our engagement with our pre-service teachers. As teacher educators of language, we are well placed to emphasise this when teaching literature to our students. The importance of scaffolding (Vygotsky, 1978), which is a concept of sociocultural theory wherein a parent or knowledgeable other creates conditions that support learning, needs to be at the forefront of our engagements with our students as we highlight the power of reading in changing lives.

We are both of the opinion that the fact that we are avid readers and have attained academic success can largely be attributed to having been read to when we were young and to our exposure to print materials. In accordance with this belief, Battye and Rainsberry (2013) reported that to develop academic success it is important not only to learn to read but to develop a love of reading. Bona may have resented her father's intervention, and Bridget taken her trips to the library for granted, but both 
had parents who were interested in, and involved with, their children's education. Caron and Ponder (2014) wrote that parents who respond to children's questions, talk to them, and read to them are building the foundation for learning to read at an early age. Such children are introduced to language and how it works at an early age. They learn the sounds of different letters and vowels. They use this knowledge as building blocks in developing and advancing their reading skills. Vygotsky's (1978) concept of the zone of proximal development (ZPD) refers to the distance between the level that the child is at, and the potential for development under the guidance of a more capable person. Brown (1992) expanded this idea and added artefacts, books, videos, and other devices as means of scaffolding learning within the ZPD. An example of this is a student taught by Bona a few years ago, and who was studying isizulu as first additional language. She was an English first-language speaker, and was a competent student. She studied six modules of isiZulu over three years. Her achievements in these modules over the three years were outstanding because she used her reading skills to source her own useful and relevant material, which enriched her knowledge of the subject content. She also consulted YouTube clips and other online sources to expand her knowledge. She attributed her success in isizulu at university to having always been a keen and avid reader and that she had been read to as a child.

Various studies attest that early parental involvement is central to learners' adjustment at school as well as to their academic success (Hill \& Craft, 2003; Jaiwal \& Choudhurie, 2017). The importance of reading to children from an early age cannot be over emphasised. Creating a positive literacy environment at home often enhances early literacy growth as accentuated by Howie (2010), who reported that the highest achievers in the 2006 PIRLS assessment were learners whose parents kept them occupied in a wide range of literacy activities from the age of six years. These activities included book reading, storytelling, and playing word games. Rose (2004) contended that the basis of inequality in the classroom can be traced to students' reading abilities, and whether or not they are able to learn from reading. Bergin (2001) concurred and, furthermore, quantified the advantage by stating that that children hailing from literate families have been exposed to an average of 1,000 hours of reading before starting school. He further suggested that the first stage in the school curriculum starts in the home when children are read to by parents or caregivers. It follows that children who begin school with this reading background have an advantage from the first day. They learn to read at a faster pace than those who were not exposed to print materials in the home. The 2016 PIRLS report is of concern because for $80 \%$ of our Grade 4 children to be unable to read for meaning begs the question as to how many of our children are exposed to reading in their formative years. As pre-service teachers of English and isizulu, we agreed to highlight the significant role that reading plays in academic development (and the disadvantages of not being readers) in as many of our modules as possible-to keep the importance of reading at the forefront of our students' minds.

While we concede that many of the children from first world countries face better prospects in terms of resources than their South African counterparts (Howie, 2010), we believe that as pre-service teacher educators of English and isizulu teaching literature, we can create awareness of the importance of reading to children and encourage those in our classes to read. We could highlight that to invest in books for their children is as important as seeing to their physical needs. To expose children to books is to broaden their knowledge base to enable them to access the privileges that come with reading. Some of our students are parents, and some have assumed the role of parent to younger siblings -it is important that we encourage those who have children at home to read to them. We need to urge our students to read the prescribed texts and to select literature with which they are able to identify. How we teach the novel is as important as the choice thereof, and exciting excerpts could be read or role-played to tweak interest. In discussions, the two of us agreed that we do not always have to be the readers when extracts from novels are read in class. When we ask students to volunteer to read a passage out aloud, we always have willing readers. It works well when there are numerous 
characters in the text. Students could be encouraged to read the novels in groups outside of class and, those who are fluent readers, to read aloud.

In our endeavours to encourage students to read, what our disciplines have done on occasion is to invite the authors of prescribed texts to address the students, which has inspired some of them not only to read the novels but also to write their own fiction. Time of the Writer, a writing festival wherein writers from Africa, South Africa, and other parts of the world get together and talk about their work is held in Durban on an annual basis. Some of the authors are invited to come to campus, meet the students, and engage with them about their writing, and there is always interest in these events. To invite the writers has had positive spin-offs in that a number of our students were inspired to write poetry and try their hand at writing short stories or a novel. Rose (2005) wrote that when students are engaged in reading, they are exposed to language patterns and their importance in the telling of stories. In this way, students come to the realisation that grammar is not a collection of isolated sentences. This reinforces what Halliday (1993) said about how language works to make meaning in context. To be a reader exposes one to the fact that all writing has a purpose, and that there are different genres within which specific language patterns are pivotal. Whilst each genre has three stages - the beginning, middle, and end-the different genres do not follow the same patterns in their writing. What determines these patterns is the conventions that dictate the genre. If our English and isizulu teachers are not readers, they will not have the wherewithal to recognise the language patterns and to alert their learners to them.

Many studies suggest that teachers who are poorly prepared contribute to the low levels of literacy in the country's education system (Baruthram 2012; Howie, Venter, \& van Staden, 2008). As pre- service teacher educators, we consider the teaching of reading proficiency and effective reading skills crucial to the preparation of our pre-service teachers for their future roles as teachers of English and isizulu. Students should be able to implement learned strategies when engaging with their wide range of academic activities, including writing. We are of the opinion that having well trained teachers who are aware of the importance of literacy, and of reading to children, could go a long way to improving the country's literacy development-which will, in turn, contribute to social change.

\section{Conclusion}

Using seemingly simple photographs as memory prompt objects to examine our literacy experiences, evoked memories of our childhoods and of the pivotal role that our parents and reading played in our academic lives. The discussions emanating from our visual representations, the diary and the poem, generated engagements about how we can influence our pre-service language teachers to recognise reading as a privilege that can contribute to social change. The importance of stressing the pivotal role that reading plays in children's lives in our English and isizulu classes became clear, and we resolved to keep promoting reading as the gateway to academic success. We also realised that we need to recognise the cultural and social capital that our students bring to class, and that a way in which this can be done is through the choices we make with our literary texts. In order to select relevant texts, we need to know our students because they will inform our choices. It is through literature that we will be in a position to broaden their perspectives on wider social issues, and we will then be well placed to challenge our students from our own social and cultural perspectives. What should follow learning to read, reading to learn, and academic success is social development for students who can then have a positive influence on others through initiating action that could bring about change in values and attitudes in their families and communities. 


\section{References}

Baruthram, S. (2012). Making a case of reading across the curriculum in higher education. South African Journal of Education, 32, 205-214.

Battye, C., \& Rainsberry, M. (2013). Reading for pleasure puts children ahead in the classroom, study finds. Retrieved from

https://www.plymouth.ac.uk/uploads/production/document/path/6/6675/BEd interview articl e Reading for pleasure puts children ahead in the classroom.pdf

Bergin, C. (2001). The parent-child relationship during beginning reading. Journal of Literacy Research, 33(4), 681-708.

Brown, A. (1992). Design experiments: Theoretical and methodological challenges in creating complex interventions in classroom settings. Journal of the Learning Sciences, 2(2), 141-178.

Caron, C., \& Ponder, C. (2014). What is the best age to teach your child to read? Learn to Read.

Retrieved from http://www.learn-to-read-prince-george.com/best-age-read.html

Carr, P. (2016). Whiteness and white privilege: Problematizing race and racism in a "color-blind" world, and in education. International Journal of critical pedagogy, 7(1), 51-72.

Clandinin, D. (2006). Narrative inquiry: A methodology for studying lived experience. Research Studies in Music Education, 27, 44-54.

Clandinin, D., \& Connelly, F. (2000). Narrative inquiry: Experience and story in qualitative research. San Francisco, USA: Jossey-Bass.

Connelly, F., \& Clandinin, D. (1990). Stories of experience and narrative inquiry. Educational Researcher, 38(8), 577-590.

Fine, M. (1998). Working the hyphens: Reinventing self and other in qualitative research. Retrieved from http://www.sfu.ca/ decaste/867fall08/867pdfs/handbook_70-82.pdf

Grabe, W. (1991). Current developments in second language reading research. TESOL Quarterly, 25, 375-406.

Halliday, M. (1993). Towards a language-based theory of learning. Linguistics and Education, 5(2), 93116.

Hill, N., \& Craft, S. (2003). Parental school involvement and children's academic achievement: Pragmatics and issues. Current Directions in Psychological Sciences, 13, 161-164.

Howie, S. (2010). The relationship between early childhood backgrounds and reading achievements in low and high achieving countries in PIRLS 2006. Paper presented at the International Research Conference for the Evaluation of Educational Achievement, Gothenburg, Sweden.

Howie, S., Venter, E., \& van Staden, L. (2008). The effect of multilingual policies on performance and progression in reading literacy in South African primary schools. Education Research and Evaluation, 14(6), 551-560.

Jaiwal, S., \& Choudhurie R. (2017). A review of the relationship between parental involvement and student's academic performance. International Journal of Indian Psychology, 4(3), 110-123.

Kitchen, J. (2009). Passages: Improving teacher education through narrative self-study. In D. Tidwell, M. Heston, \& L. Fitzgerald (Eds.), Research methods for the self-study of practice (pp. 35-51). New York, USA: Springer.

Lantolf, J., \& Thorne, S. L. (2007). Sociocultural theory and second language learning. In B. van Petten \& J. Williams (Eds.), Theories in second language acquisition (pp 201-224). Mahwah, USA: Lawrence Erlbaum. 
Lofting, H. (1967). The voyages of Dr Doolittle. Philadelphia, USA: J. B. Lippincott.

Mclntosh, P. (1988). White privilege: Unpacking the invisible knapsack. Retrieved from https://www.racialequitytools.org/resourcefiles/mcintosh.pdf

McKenna, S. (2010). Cracking the code of academic literacy: An ideological task. In C. Hutchings \& J. Garraway (Eds.), Beyond the university gates: Provision of extended curriculum programmes in South Africa (pp. 8-15). Grahamstown, South Africa: Rhodes University. Retrieved from https://www.cput.ac.za/storage/services/fundani/beyond_the_university_gates.pdf

Mitchell, C. (2017). Object as subject: Productive entanglements with everyday objects in educational research. In D. Pillay, K. Pithouse-Morgan, \& I. Naicker (Eds.), Object medleys: Interpretive possibilities for educational research (pp. 11-28). Rotterdam, Netherlands: Sense.

Mitchell, C., \& Pithouse-Morgan, K. (2014). Expanding the memory catalogue: Southern African women's contributions to memory-work writing as a feminist research methodology. Agenda: Empowering women for gender equity, 28(1), 92-10.

Pithouse, K. (2011). "The future of our young children lies in our hands": Re-envisaging teacher authority through narrative self-study. In C. Mitchell, T. Strong-Wilson, K. Pithouse, \& S. Allnutt (Eds.), Memory and pedagogy (pp. 177-190). New York, USA: Routledge.

Potter, B. (1964). The Tale of Peter Rabbit. London, UK: Penguin.

Prosser, J. (2011). Visual methodology: Toward a more seeing research. In N. K. Denzin \& Y. S. Lincoln (Eds.), Collecting and interpreting qualitative materials (pp. 223-261). Thousand Oaks, USA: SAGE.

Prown, J. (1982). Mind in matter: An introduction to material culture theory and method. Winterthur Portfolio, 17(1), 1-19.

Riggins, S. (1994). Fieldwork in the living room: An autoethnographic essay. In S. H. Riggins (Ed.), The socialness of things: Essays on the socio-semiotics of objects (pp. 101-147). Berlin, Germany: Moutin de Gruyter.

Rose, D. (2004). Sequencing and pacing of the hidden curriculum: How Indigenous children are left out of the chain. In J. Muller, A. Morais, \& B. Davies (Eds.), Reading Bernstein, researching Bernstein (pp. 91-107). London, UK: RoutledgeFalmer.

Rose, D. (2005). Democratising the classroom: A literary pedagogy for the new generation. Journal of Education, 37, 131-167.

Spaull, N. (2017). The unfolding reading crisis: The new PIRLS 2016 results ... Retrieved from https://nicspaull.com/2017/12/05/the-unfolding-reading-crisis-the-new-pirls-2016-results/

Thobejane, T. (2013). History of apartheid education and the problem of reconstruction in South Africa. Sociology Study, 3(12), 1-12.

van Boxtel, C. (2000). Collaborative concept learning: Collaborative learning tasks, student interaction and the learning of physics concepts. Utrecht, Netherlands: University of Utrecht.

Vygotsky, L. (1978). Mind in society: The development of higher psychological processes. Cambridge, USA: Harvard University Press.

Warner, M. (2004). Introduction. In M. Hayworth-Booth (Ed). Things: A spectrum of photography 1850-2001 (pp. 1-4). London, UK: Jonathan Cape.

Wertsch, J. (1991). Voices of the mind: A sociocultural approach to mediated action. Cambridge, USA: Harvard University Press.

Yeo, L., Ong, W., \& Ng, C. (2014). The home literacy environment and preschool children's reading skills and interest. Early Education and Development, 25(6), 791-814. 